Corporatism and Unemployment in the 1980s and 1990s

Author(s): Lane Kenworthy

Source: American Sociological Review, Vol. 67, No. 3 (Jun., 2002), pp. 367-388

Published by: American Sociological Association

Stable URL: http://www.jstor.org/stable/3088962

Accessed: 16-11-2015 12:19 UTC

Your use of the JSTOR archive indicates your acceptance of the Terms \& Conditions of Use, available at http://www.jstor.org/page/ info/about/policies/terms.jsp

JSTOR is a not-for-profit service that helps scholars, researchers, and students discover, use, and build upon a wide range of content in a trusted digital archive. We use information technology and tools to increase productivity and facilitate new forms of scholarship. For more information about JSTOR, please contact support@jstor.org.

Sage Publications, Inc. and American Sociological Association are collaborating with JSTOR to digitize, preserve and extend access to American Sociological Review. 


\title{
CORPORATISM AND UNEMPLOYMENT IN THE 1980S AND 1990s
}

\author{
LANE KENWORTHY \\ Emory University
}

\begin{abstract}
A number of studies have found an association between corporatist institutions and low unemployment in the 1970s and/or 1980s. Three gaps in our understanding of corporatism's labor market effects are addressed here: (1) Which of the two principal forms of corporatism-corporatist wage-setting or union participation in economic policymaking, or both-generates these effects? (2) What are the causal mechanisms? (3) Did these effects continue in the 1990s in the face of globalization, restrictive monetary policy, growing dissension within labor movements, and related developments? The impact of corporatism across 16 affluent $O E C D$ countries in the 1980s and 1990s is assessed using pooled time-series cross-section analysis. The results suggest that wage coordination was conducive to low unemployment in the 1980s because it fostered moderation in labor costs, spurred faster economic growth, and encouraged governments to more aggressively pursue policies to reduce unemployment. In the 1990s, this effect disappeared, largely because unemployment outcomes in low wage-coordination countries improved rather than because unemployment outcomes in high wage-coordination countries deteriorated. Union participation in economic policymaking was associated with low unemployment throughout the two decades, conditional on the presence of leftist government. Union participation appears to have had this effect mainly via government policy.
\end{abstract}

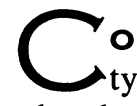

ORPORATISM refers to various types of institutional arrangements whereby important political-economic decisions are reached via negotiation between, or in consultation with, peak-level representatives of employees and/or employers, sometimes involving other interest groups and the state. One of the best-known forms of corporatism is centralized wage-setting, in which wages for a large portion of the work

Direct all correspondence to Lane Kenworthy, Department of Sociology, Emory University, Atlanta, GA 30322 (lkenwor@emory.edu). For helpful comments I thank Alex Hicks, Bernhard Kittel, and the $A S R$ reviewers, as well as Art Alderson, Anke Hassel, Fritz Scharpf, Michael Smith, Wolfgang Streeck, and Michael Wallerstein. I am also grateful to Stephen Nickell for allowing me access to data from the Centre for Economic Performance. Portions of this paper were written while I was a visiting scholar at the Max Planck Institute for the Study of Societies in Cologne, Germany. force are bargained by national union and employer confederations. A second important form is participation by such confederations in the formation of government decisions about nonwage issues such as fiscal policy, monetary policy, active labor market policy, and so on. Corporatist arrangements have been among the key political-economic institutions in a number of affluent capitalist nations since the 1960s. They have thus been of substantial interest to macro-comparative sociologists, political scientists, and economists.

A number of studies have found an association between the prominence of corporatist institutions and low unemployment in the 1970s and/or 1980s (Bruno and Sachs 1985; Calmfors and Driffill 1988; Cameron 1984; Compston 1997; Garrett 1998; Hall and Franzese 1998; Hicks and Kenworthy 1998; Iversen 1999; Janoski, McGill, and Tinsley 1997; Layard, Nickell, and Jackman 1991; Scharpf [1987] 1991; Soskice 1990). Unem- 
ployment is one of the most important economic outcomes in affluent countries. It is a major contributor to individual unhappiness (Clark and Oswald 1994) and to societal ills such as poverty, neighborhood decay, and crime (Chiricos 1987; Wilson 1996); it also impedes economic growth (Okun 1973) and is a potential threat to the welfare state (Esping-Andersen 1999). Large-scale unemployment has arguably been the prime economic, social, and political issue in much of Western Europe over the past two decades.

I attempt to answer three questions that reflect notable gaps in previous research linking corporatism with low unemployment: (1) Are corporatism's effects on unemployment generated by both corporatist wage-setting and union participation in economic policymaking, or by only one of these forms of corporatism? (2) What are the causal mechanisms through which such effects occur? (3) Did these effects continue in the 1990s in the face of globalization, restrictive monetary policy, growing dissension within labor movements, and related developments?

\section{THREE QUESTIONS}

\section{WHICH FORM OF CORPORATISM?}

The focus of most research on corporatism's macroeconomic effects has been on wagesetting arrangements. Yet some scholars view corporatism as participation by organized interest groups in various types of public policymaking. This conception, originally highlighted by Lehmbruch (1984), has received relatively little attention in the empirical literature during the past two decades. Indeed, only three studies have examined the effect of union participation in policymaking on unemployment (Boreham and Compston 1992; Compston 1997; Traxler, Blaschke, and Kittel 2001:227-31). Each found a beneficial effect.

No prior study has examined the macroeconomic impact of these two principal forms of corporatism in conjunction. Analyses of corporatist wage-setting have not controlled for union participation in policymaking, and vice-versa. These two forms are likely to be correlated with one another, raising the possibility that at least some of the existing research has mistakenly emphasized the wrong form of corporatism.

\section{What ARE the Causal Mechanisms?}

Among researchers interested in wage determination, the predominant notion has been that centralized or coordinated wage-setting yields low unemployment by engendering real wage restraint. (I use the term "wages" throughout as shorthand for wages plus benefits.) The general logic is relatively simple, although specific applications of it can be complex (Franzese 1999; Organization for Economic Cooperation and Development [OECD] 1997). If employees bargain aggressively for high wage increases and employers acquiesce, the latter can do five main things in response: raise productivity, raise prices, reduce profits paid out to investors, reduce investment, and/or reduce the number of employees. Where wages are bargained at a large number of separate firms or plants, each individual union may reasonably hope that its employer's response to a pay increase will consist predominantly of some combination of the first four options. None of these responses will necessarily have an adverse short-term effect on employment or inflation-adjusted wages, which are the principal concerns of union negotiators. Even if the firm chooses to reduce employment, those laid off should be able to find work elsewhere as long as the pattern of wage increases and layoffs is not generalized throughout the economy. Thus, where bargaining is decentralized and uncoordinated, there is an incentive for unions to pursue a strategy of wage militancy.

By contrast, if the wage negotiations cover a relatively large share of the work force, union bargainers can be reasonably sure that a large wage increase will have an adverse impact on their members. For instance, when an individual firm raises prices, this is likely to have little or no effect on the living standard of that firm's own employees (unless the company's goods or services happen to account for a large share of what those employees consume). But when firms representing a sizable share of the economy raise prices, the resulting inflation offsets or nullifies the wage gains of most workers. Similarly, a reduction in employment at a single 
firm does not necessarily reduce the job prospects for workers who are laid off; but if wage increases and ensuing layoffs are economy-wide, employment opportunities will diminish. Centralized or coordinated wage-setting thus generates an incentive for wage moderation.

Wage moderation, in turn, is presumed to contribute to lower unemployment. The assumption is that slower growth of real labor costs (often referred to as "real unit labor costs") leads to lower unemployment. "Labor costs" refer to wages and benefits adjusted for productivity, and "real" denotes adjustment for inflation. If wage increases are offset by increases in productivity and/ or prices, then real labor costs have not increased. Consequently, there is no need for employers to reduce payments to investors, investment, or employment. However, if real labor costs do increase, one result-perhaps the main result - will be a higher unemployment rate as employers respond by reducing the size of their work force.

Some researchers have focused on the effects of wage-bargaining centralization, while others have emphasized wage coordination. Centralization refers to the level(s)peak, sectoral, company/plant-at which wages are determined. Coordination refers to the degree to which minor players in the wage-setting process (e.g., firm- or plantlevel bargainers) intentionally follow along with what the major players decide. Bargaining centralization is one means of achieving coordination. A second is state-imposed centralization, as in Belgium, the Netherlands, Denmark in some years, and even Canada and the United States in a few years. A third is guidance of industry or firm-level bargaining by peak union and/or employer confederations, as in Switzerland, Austria (prior to the mid-1980s), Norway (in a number of years), the Netherlands (since 1983), and Italy (since 1993). This might be termed "informal centralization." In informal centralization, union and/or employer confederations tacitly centralize the bargaining process by suggesting and/or approving wage agreements that are formally negotiated at lower levels, or sometimes simply by sharing information and fostering a climate of consensus. A fourth means of achieving coordination is pattern-setting led by a power- ful sector, as in Germany, or by a group of influential firms, as in Japan. Pattern-setting exists where bargaining is formally decentralized, but in practice one or a few wage settlements (e.g., the metalworkers' settlement in Germany) are seen by all or most other bargaining parties as determining the outcome that they will follow.

Centralization has received the bulk of attention in the corporatist literature. But to understand the effects of wage-setting institutions on labor cost developments and unemployment, it makes more sense to focus on wage coordination (Flanagan 1999:1172; Soskice 1990; Traxler and Kittel 2000). The key is that major players have an incentive to moderate labor costs and minor players tend to adhere to what the major players decide. Pattern-setting and informal bargaining centralization are likely to be just as effective as formal centralization at generating this set of incentives and behaviors. The limited empirical evidence accumulated thus far has generally been supportive (Hall and Franzese 1998; Nickell and Layard 1999; Soskice 1990; Traxler and Kittel 2000).

If labor cost restraint has been the principal presumed link between wage-setting arrangements and unemployment, a second link is economic growth. One of the outcomes of wage coordination, achieved either informally or explicitly in corporatist pacts, may be greater investment, which in turn tends to spur more rapid growth of economic output (Alvarez, Garrett, and Lange 1991; Hicks 1988). Faster economic growth generally helps to reduce the unemployment rate.

A third view holds that the mechanism linking corporatist wage-setting with low unemployment is government policy. Policy orientations, in this conception, are a key determinant of cross-country differences in unemployment rates (Hibbs 1977; Korpi 1991; Soskice 2000; Therborn 1986). Policymakers in countries with coordinated wage-setting are likely to feel more confident than their counterparts in countries with fragmented bargaining that labor cost increases will be moderate. Thus, they should tend to worry less about wage-push inflation. This may increase their willingness to pursue stimulative monetary and/or fiscal policy, active labor market policy, public employment, or other programs that 
reduce unemployment. By contrast, policymakers in nations with less coordinated wage arrangements may feel compelled to resort to higher levels of unemployment in order to keep inflation in check (Hall and Franzese 1998; Kenworthy 1996; Soskice 1990). Note that this hypothesis does not imply that the rate of labor cost increase necessarily will be lower in high-coordination countries than in low-coordination ones, only that policymakers in high-coordination countries will tend to have greater confidence that labor cost increases will be moderate.

Among the nations with relatively coordinated wage-setting, Sweden and Denmark have relied heavily on active labor market policy and public employment, Norway and Austria on investment by the publicly owned business sector and government subsidies to business, Germany on education and job training, Japan on government support for the practice of "lifetime employment" in large firms, Switzerland on displacement of foreigners from the labor market, and Ireland on stimulative fiscal policy. The evidence suggests that these various policy strategies have been effective (Boix 1998, chap. 3; Layard et al. 1991; Martin 20002001; Nickell and Bell 1996; Therborn 1986). And there is reason to believe that coordinated wage-setting has played a causal role in the development and sustained use of many of these strategies. In some instances, wage coordination is one element in an array of interlinked institutions that reinforce one another (Dore 1987; Soskice 1999; Streeck 1997). In the absence of wage coordination, other elements of the institutional configuration, such as a particular policy approach toward joblessness, might be weakened. In other cases, anti-unemployment policies are introduced or continued as part of an explicit "political exchange" for union wage restraint (Pochet and Fajertag 1997; Visser and Hemerijck 1997).

How might union participation in economic policymaking affect unemployment? Unions typically desire low unemployment. Thus, the more input unions have into economic policy decisions, the more likely it is that government policies will prioritize low unemployment (Boreham and Compston 1992; Compston 1997). To the extent that such policies are effective, the result should be lower rates of joblessness.

I empirically explore these hypothesized causal links between wage coordination, union participation in policymaking, and unemployment. Only a few cross-country studies of corporatism have actually examined the relationship between wage-setting and labor cost developments. Most have looked only at the relationship between wage-setting and unemployment and have simply presumed that the link between wage-setting and labor cost restraint (and also between labor cost restraint and unemployment) occurs as hypothesized. The few prior studies to assess this link yielded inconclusive results and were somewhat limited in scope. Bruno and Sachs (1985), Layard et al. (1991, chap. 9), and Western and Healy (1999) all found an association between corporatist wage-setting and real wage restraint. Because of limited data availability, however, these studies examined wages only in the manufacturing sector. Although manufacturing historically has been a pacesetter for wage developments in the rest of the economy, it has accounted for only one-fifth of total employment in most affluent countries in recent decades. Thus, it is important to examine wage patterns in other sectors as well. A recent OECD (1997) study used wage data for the entire economy and found no association between wage centralization or coordination and changes in real wages. That analysis, however, was based on a highly underspecified model. In addition, each of these previous studies focused on wages, despite the fact that the theory specifies a link with labor costs. ${ }^{1}$

I am not aware of any empirical assessments of the hypothesis that corporatismin the form of wage-setting and/or union participation in economic policymaking-affects unemployment via government policy.

1 Western and Healy's (1999) study was not aimed at examining the mechanism linking corporatism with low unemployment and so had no reason to consider labor costs. Kenworthy (1996) and Traxler and Kittel (2000) each found links between wage-setting and nominal labor cost restraint and between nominal labor cost restraint and low inflation. But neither study examined real labor costs, which are presumed to be the mechanism through which corporatism generates low unemployment. 
Boreham and Compston (1992), Compston (1997), and Traxler et al. (2001:227-31) found union participation to be associated with low unemployment, but they did not test the purported intervening mechanism(s).

\section{DID CORPORATIST EFFECTS CONTINUE IN THE 1990s?}

Existing research has been confined to the 1970s and 1980s. Did corporatist effects continue in the 1990s? ${ }^{2}$ There are five plausible scenarios.

(1) Corporatist effects weakened or disappeared-because corporatist institutions became less effective at generating low unemployment than in previous decades. ${ }^{3}$ First, coordinated wage-setting may have become less able to secure labor cost moderation, as wage drift at the firm- or plant-level increasingly offset the restraint generated in coordinated negotiations. The chief cause of this wage drift is thought to be dissension among different segments of the work force, particularly over the issue of relative pay levels (Ahlen 1989; Hernes 1991). One important division is among private-sector blue-collar, private-sector white-collar, and public-sector employees; another is among highly skilled versus semiskilled and unskilled employees.

A second reason why corporatist countries may have been less able to secure low unemployment in the 1990s is declining policy autonomy. Loose monetary policy is one way to stimulate the economy and thereby hold down the rate of joblessness, but various aspects of globalization encouraged policymakers in most affluent nations to pursue a restrictive monetary policy in the 1990s (Boix 2000; Scharpf and Schmidt

2 A few studies, such as Iversen (1999), Nickell and Layard (1999), and Western (2001), included the early 1990 s but did not examine the possibility of changes in effects during these years.

${ }^{3}$ A decline in wage coordination's prominence can be misinterpreted as a decline in its effectiveness. Wage coordination decreased in Sweden and Australia in the 1990s. If these countries were less successful at securing wage restraint and low unemployment in the 1990s than they formerly had been, that might be due to the reduction in wage coordination's prominence rather than to a reduction in its effectiveness.
2000). In some countries, this reflected a desire to comply with the low-inflation requirement for European monetary integration. In all nations it is partly a product of heightened financial globalization-in particular, the growing importance of currency speculators in determining currency values. By the mid-1990s, more than $\$ 1$ trillion in currencies was traded each day, much of it by speculators using low inflation as their principal criterion for selecting currencies in which to invest (Woodall 1995:10). Massive currency sell-offs provoked by even moderate inflation-or expected inflation, as gauged by low domestic interest rates and/or sizable government deficits-are embarrassing to government officials and potentially highly destabilizing (Krugman 1998). Convergence in monetary policy removed one important tool that governments in corporatist countries may have formerly used to influence the unemployment rate. In addition, the heightened ease of capital exit may have pressured policymakers in corporatist countries to cut back on other programs for reducing unemployment, such as education, active labor market policy, and public employment.

(2) Corporatist effects weakened or disappeared-because noncorporatist institutions became more effective at generating low unemployment than in previous decades. Growing international trade and heightened integration of financial markets have increased the competitive pressures faced by many firms and also enhanced companies' ability to move to other countries. These developments have increased employers' motivation to demand labor cost moderation as well as their leverage vis-à-vis employees. Hence, labor cost restraint may have become more common in countries with fragmented wagesetting institutions, eroding the difference between low-coordination and high-coordination countries (Streeck 1984; Windolf 1989). In this view, corporatism's effects disappear in the 1990s because low-coordination countries are increasingly able to restrain labor costs and hence can achieve the low levels of unemployment formerly confined to high-coordination countries.

(3) Corporatist effects persisted. Many observers have expressed skepticism about the degree to which globalization has altered 
institutional structures and policy choices in the rich OECD countries (Berger and Dore 1996; Campbell 2000; Garrett 1998; Kenworthy 1997; Kitschelt et al. 1999). Furthermore, both globalization and growing work force divisions were already present to a significant degree in the 1980 s. Perhaps, then, whatever impact corporatist institutions had in the 1980s continued in the 1990s.

(4) Corporatist effects increased-because corporatist institutions became even more effective at generating low unemployment than in previous decades. With monetary policy lost as a policy tool, union wage negotiators interested in political exchange or union representatives directly involved in economic policymaking may have turned their attention to active labor market policy, government employment, or other programs aimed at reducing joblessness. To the extent that these programs succeeded, the unemployment gap between corporatist and noncorporatist countries might have widened in the 1990s.

(5) Corporatist effects increased-because noncorporatist institutions became even less effective at generating low unemployment than in previous decades. With all nations committed to a tight money orientation, "excessive" increases in labor costs may have been even more likely in the 1990s to result in higher unemployment because governments were increasingly unable to "monetize" such labor cost increases (i.e., to allow higher inflation in order to prevent a rise in unemployment). Thus, if fragmented wage-setting continued to promote wage militancy, the unemployment performance of noncorporatist countries may have worsened in the 1990s.

\section{METHOD, DATA, AND VARIABLES}

I use pooled time-series cross-section regressions to explore the effects of wage coordination and union participation in economic policymaking on unemployment over the period 1980 to 1997. Sixteen affluent OECD countries are included: Austria, Belgium, Canada, Denmark, Finland, France, Germany, Ireland, Italy, Japan, the Netherlands, Norway, Sweden, Switzerland, the United Kingdom, and the United States. Data for unemployment and many of the in- dependent variables are available through 1999, but because of data limitations for the union participation variable the analysis covers only the period through 1997. All variables are described in Table 1.

Some scholars suggest that the employed share of the working-age population is a more telling indicator of labor market performance than the unemployment rate (Scharpf 1999:125-26; Smith 1999). Unemployment, after all, can be "hidden" by low levels of labor force participation (as in Italy, Belgium, and Ireland) or by various active labor market, early retirement, and other social-welfare policies (as in Sweden). Yet using the employment rate as an indicator of labor market outcomes is not without problems, particularly because nations differ in the frequency with which women, especially married women, participate in the paid labor force. This variation, which is a result of differing cultural traditions and government policies, yields sizable cross-country differences in employment rates that have little or nothing to do with the health of the labor market. Therefore, despite its limitations, unemployment remains a preferable indicator (also see Nickell 1997). As it turns out, the causal patterns are similar for these two measures of labor market performance. (These and other results not shown here are available from the author on request.)

The wage-coordination variable is my own (Kenworthy 2001a). It is an index ranging from 1 to 5 . This is the only existing coordination variable that is measured annually and provides scores through the late 1990s. Unlike other coordination indicatorsSoskice (1990), Layard et al. (1991), OECD (1997), Hall and Franzese (1998) -it does not attempt to capture the degree of actual wage coordination in each country. It is extremely difficult to measure the degree to which the various actors involved in the wage-setting process deliberately harmonize their bargaining. To do so, the researcher must factor in both the share of the work force whose wages are deliberately pegged to the agreement(s) reached by the major player(s) and the degree to which minor players follow along (how closely they adhere). This information is not easily discernible, much less readily available. Existing measures thus tend to be highly impression- 
istic (see Kenworthy 2001b). My scores are based instead on a set of expectations about which institutional features of wage-setting arrangements are likely to generate more or less coordination. This avoids the problem of limited information about the intentions of various actors in the wage-setting process and the difficulty in ranking those intentions even if such information were available. The rationale for the scoring is explained in greater detail in Kenworthy (2001a, 2001b). Despite the difference in measurement strategy, this index is closely correlated $(r=.88$ or better) with the Soskice, OECD, and HallFranzese coordination measures. ${ }^{4}$

The union participation in economic policymaking variable is from Compston (1997). It is an index ranging from 0 to 10 , with annual scores. The index aims to capture the degree of union input into the economic policymaking process, ranging from no representation at all to broad agreement with policymakers. Compston's scores go only through 1992, but I have extended them through 1996 based on information in a recent article by Compston (1998) and, for two countries, on extrapolation. Compston (1997) suggests that the effect on unemployment of union participation in policymaking is likely to lag one to two years, and in his statistical analysis he uses an average of the scores for the previous two years. I do the same here. Given that his (extended) scores go through 1996, I can examine unemployment outcomes through 1997. Unfortunately, the Compston measure is available for only 13 countries. Among the 18 OECD nations commonly included in comparative research on corporatist effects, Australia, Canada, Japan, New Zealand, and the United States are omitted. I have added scores for Canada, Japan, and the United States. These three countries are almost certain to be on the low end, except that in the early 1990s Japanese unions began to participate somewhat extensively in peak-level tripartite bodies. ${ }^{5}$ Union

4 These correlations are based on a 1974-1989 period average, as the other wage-coordination measures are time-invariant (see Kenworthy 2001b).

${ }^{5}$ This is consistent with the scores for the only other measures of this kind, those of Lehmbruch (1984:66) and Traxler et al. $(2001: 76,312)$. I do participation in policymaking should have greater influence on policy decisions, and thereby generate lower unemployment, in a context of sympathetic government. I thus include a union participation $\times$ leftist government interaction term in the regressions. A negative coefficient is expected for this variable.

I include a variety of control variables. Each has been found in previous studies to affect employment performance and may be correlated with wage coordination and/or union participation in policymaking (Hall and Franzese 1998; Kenworthy 2002; Korpi 1991; Nickell and Layard 1999; Scarpetta 1996; Western 2001). (1) Trade: Unemployment in nations more heavily dependent on trade may be influenced to a greater extent by trends in the international economy. (2) Union density: Controlling for wage coordination, more extensive unionization is expected to generate greater labor cost increases and therefore produce higher unemployment. (3) Employment regulations: This index gauges the strictness of legislation on working time, fixed-term contracts, employment protection, minimum wages, and employees' representation rights on works councils and company boards. These types of regulations are commonly believed to weaken employers' willingness to hire additional employees. (4) Tax rate on a typical employee: This is a measure of the tax wedge between labor costs for firms and take-home pay for workers. A higher wedge is expected to reduce employer demand for labor. (5) Duration of eligibility for unemployment benefits: The longer one can receive unemployment compensation, the weaker the incentive to get a new job.

The causal links between corporatism and macroeconomic performance are explored using seven variables. Wage restraint is measured with an index of real labor costs. The index is set at $1979=1$ for each country to control for preexisting cross-national differences in labor costs and thereby focus on developments in the 1980s and 1990s. Eco-

not use those measures because Lehmbruch's is based on the late 1970 s and early 1980 s and the Traxler et al. scores suggest very little variation over time in union participation in the policymaking process. 


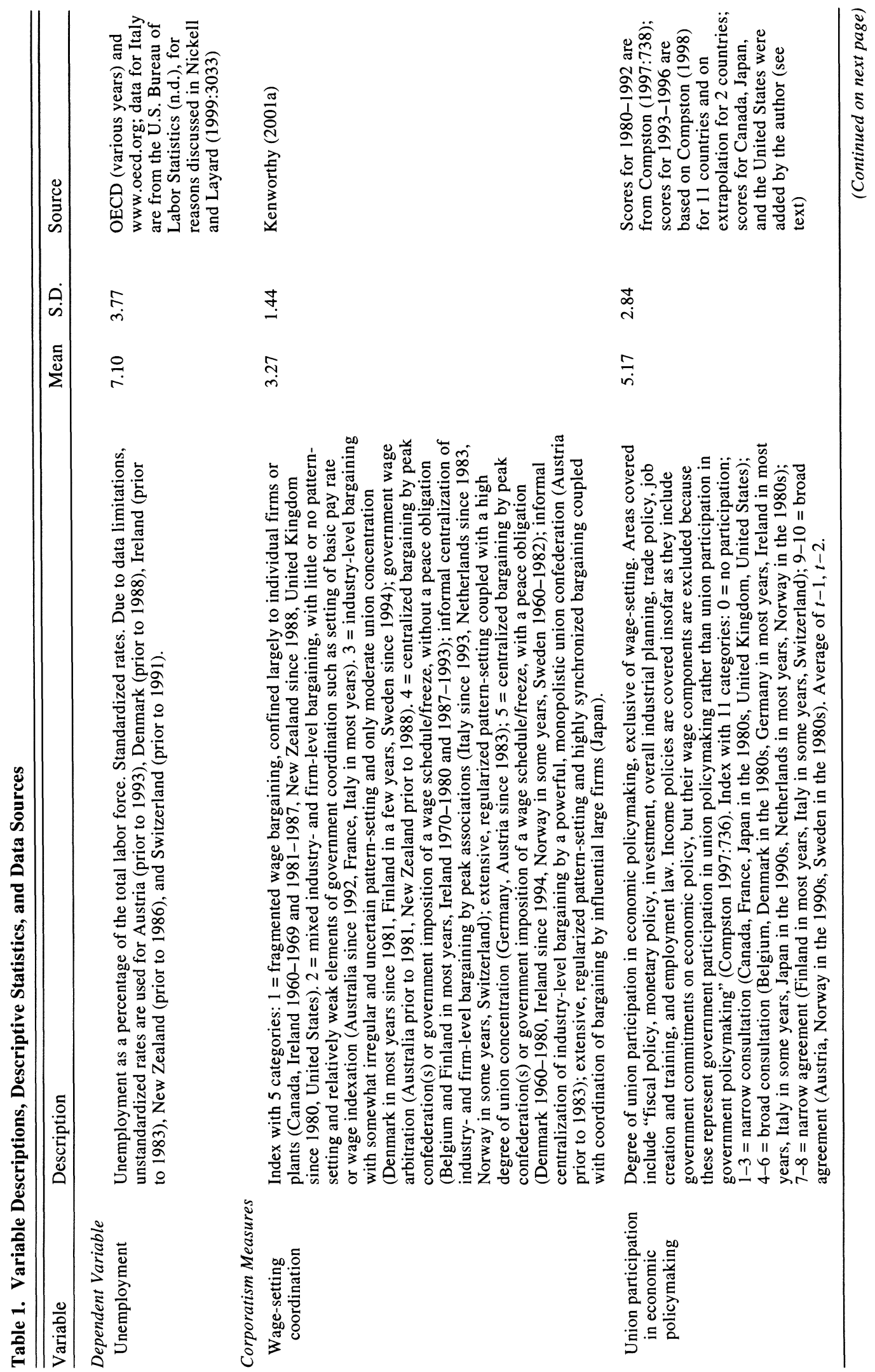




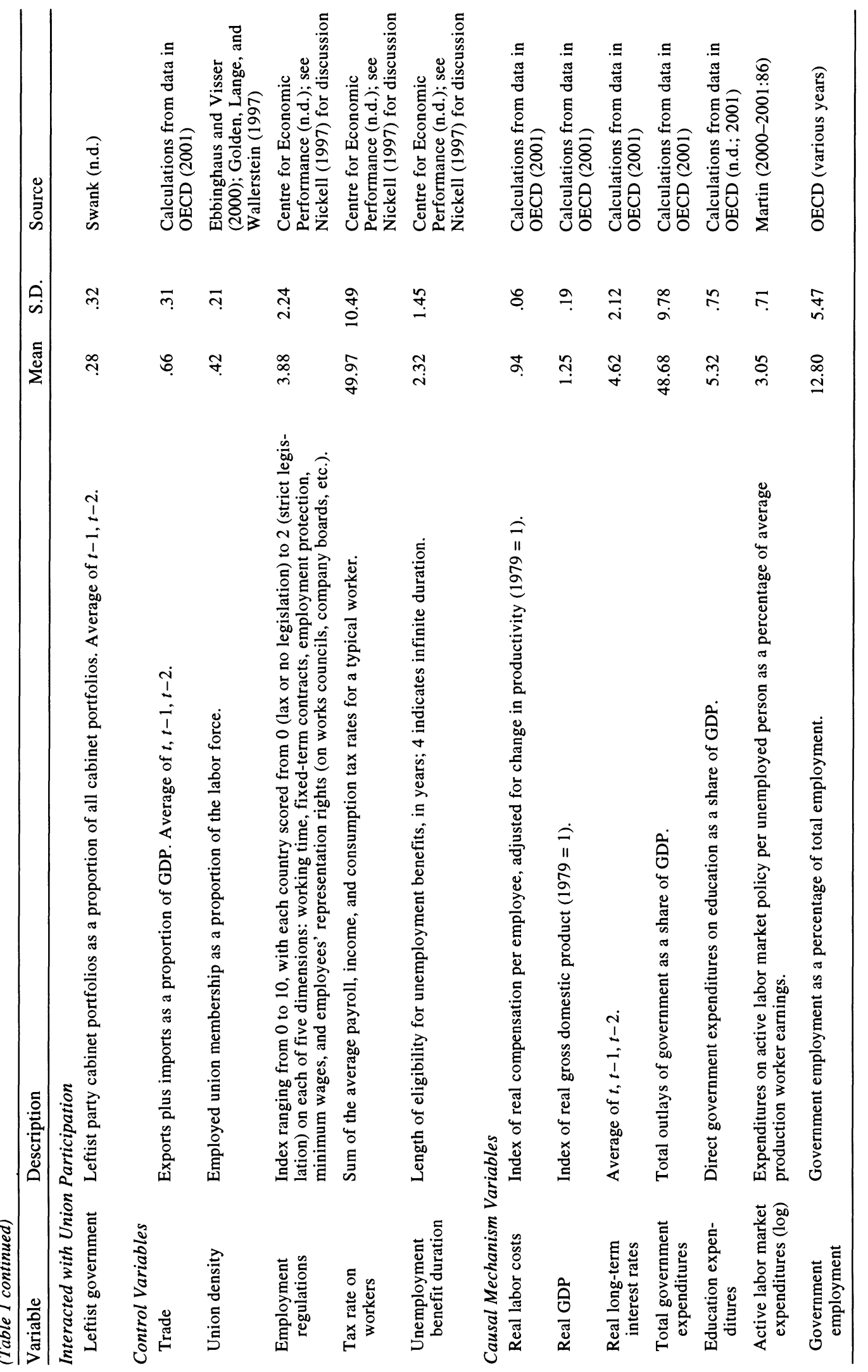


nomic growth is operationalized with an index of real gross domestic product (GDP), also with $1979=1$. Five indicators assess the notion that corporatism affects unemployment via government policy choices: real long-term interest rates, total government expenditures, government expenditures on education, government expenditures on active labor market policy, and government employment.

The regressions use annual data in a pooled time-series cross-section design. Following common practice in recent comparative political economy research, I estimate the models using ordinary least squares (OLS) with panel-corrected standard errors (Beck and Katz 1995). Similar results were obtained using "HC3" standard errors (Long and Ervin 2000) as well as random-effects generalized least squares (GLS) with robust standard errors. Unemployment rates in affluent countries tend to be sticky over time; one of the best predictors of a country's unemployment rate in a given year is its unemployment rate in the previous year. I therefore include the lagged (one-year) unemployment rate as a regressor. This also helps avert autocorrelation. A country fixed-effects model cannot be used here because several of the key independent variables, including the wage-coordination variable, do not vary over time for a number of countries. In this circumstance, the best course is to focus on the cross-sectional variation by including year dummy variables without country dummy variables (Beck and Katz 2001; Traxler et al. 2001:27-28). This is consistent with the cross-country focus of most prior research on this issue. A test for unit roots revealed no problem with nonstationarity in the dependent variable. ${ }^{6}$

To test the possibility of a structural break in effects, I use a dummy variable that divides the 1980-1997 period into two subperiods. It is coded 0 for each observation prior to a given year and coded 1 for observations from that year forward. Each of the two corporatism variables is interacted with this dummy variable. I examine 18 regressions, each with a different year used to de-

${ }^{6}$ The null hypothesis of nonstationarity for the Im-Pesaran-Shin test (see Im, Pesaran, and Shin 1997) was rejected at the $p<.001$ level. fine the subperiods. This allows the data to determine if and when a structural break in effects has occurred (Western and Healy 1999). The year 1990 marks the start of a new business cycle, and it begins a period in which policymakers in a number of countries became increasingly worried about lowering inflation in order to meet the criteria for European unification and to avoid currency sell-offs. Thus, there is reason to suspect that if a break occurred, it took place sometime around the turn of the decade. Because these regressions include a period dummy variable, I drop the dummy variables for individual years. ${ }^{7}$

\section{FINDINGS}

\section{WAGE COORDINATION}

Model 1 in Table 2 shows the regression results for the two corporatism indicators plus the control variables and the lagged unemployment rate. The results suggest a negative effect of wage coordination on unemployment. ${ }^{8}$

Model 2 adds the wage coordination $\times$ period interaction term (and a similar interaction for union participation in policymaking $\times$ period, discussed below). In regressions searching for a break in effects using all possible periodizations, the $t$-value for the interaction term and the R-squares for the equation are largest in the regression using 1992 as the break point. I therefore use this periodization in the Model 2 regression. The results indicate that wage coordination reduced unemployment between 1980 and 1991, but not thereafter. In the 1992-1997 period there is no effect, as the coefficient for the wage-coordination variable (which estimates the effect for 1980-1991) almost

${ }^{7}$ Leaving the year dummy variables in the regression requires dropping the period dummy variable, although interpretation of the interaction term remains the same. Doing this yields similar results.

${ }^{8}$ To check to see if this effect is genuinely linear, I tried entering wage coordination as a set of dummy variables representing the various categories. This allows comparison of effects for each specific level of wage coordination. The results suggest that the relationship is indeed linear. 
Table 2. Unstandardized OLS Coefficients from Regressions of Unemployment on Corporatism Variables and Control Variables: 1980s and 1990s

\begin{tabular}{|c|c|c|c|c|}
\hline \multirow[b]{2}{*}{ Independent Variable } & \multicolumn{2}{|c|}{$1980-1997$} & \multirow{2}{*}{$\frac{1980-1991}{\text { Model } 3}$} & \multirow{2}{*}{$\frac{1992-1997}{\text { Model } 4}$} \\
\hline & Model 1 & Model 2 & & \\
\hline Wage coordination & $\begin{array}{r}-.11^{*} \\
(.05)\end{array}$ & $\begin{array}{l}-.23^{* *} \\
(.06)\end{array}$ & $\begin{array}{l}-.19^{* *} \\
(.07)\end{array}$ & $\begin{array}{l}-.03 \\
(.12)\end{array}$ \\
\hline Wage coordination $\times 1992-1997$ period dummy & - & $\begin{array}{l}.24^{* *} \\
(.09)\end{array}$ & - & - \\
\hline $\begin{array}{l}\text { Union participation in economic policymaking } \\
\times \text { leftist government }\end{array}$ & $\begin{array}{l}-.18^{* *} \\
(.06)\end{array}$ & $\begin{array}{l}-.20^{* *} \\
(.06)\end{array}$ & $\begin{array}{l}-.10 \\
(.06)\end{array}$ & $\begin{array}{l}-.31^{* *} \\
(.07)\end{array}$ \\
\hline $\begin{array}{l}\text { Union participation in economic policymaking } \\
\times \text { leftist government } \times 1992-1997 \text { period dummy }\end{array}$ & - & $\begin{array}{r}-.12^{*} \\
(.05)\end{array}$ & - & - \\
\hline Union participation in economic policymaking & $\begin{array}{l}.06^{*} \\
(.03)\end{array}$ & $\begin{array}{l}.02 \\
(.03)\end{array}$ & $\begin{array}{l}.01 \\
(.04)\end{array}$ & $\begin{array}{l}.05 \\
(.05)\end{array}$ \\
\hline Leftist government & $\begin{array}{l}1.19^{* *} \\
(.37)\end{array}$ & $\begin{array}{l}1.56^{* *} \\
(.44)\end{array}$ & $\begin{array}{l}1.13^{* *} \\
(.45)\end{array}$ & $\begin{array}{l}1.35^{*} \\
(.59)\end{array}$ \\
\hline 1992-1997 period dummy & - & $\begin{array}{c}-.32 \\
(.50)\end{array}$ & - & - \\
\hline Trade & $\begin{array}{c}-.43 \\
(.28)\end{array}$ & $\begin{array}{l}-.15 \\
(.31)\end{array}$ & $\begin{array}{c}.17 \\
(.40)\end{array}$ & $\begin{array}{c}-.72^{*} \\
(.28)\end{array}$ \\
\hline Union density & $\begin{array}{c}.50 \\
(.39)\end{array}$ & $\begin{array}{l}.82^{*} \\
(.39)\end{array}$ & $\begin{array}{c}.32 \\
(.38)\end{array}$ & $\begin{array}{c}.97 \\
(.66)\end{array}$ \\
\hline Employment regulations & $\begin{array}{c}.06 \\
(.06)\end{array}$ & $\begin{array}{c}.08 \\
(.06)\end{array}$ & $\begin{array}{c}.04 \\
(.07)\end{array}$ & $\begin{array}{c}.16 \\
(.12)\end{array}$ \\
\hline Tax rate on workers & $\begin{array}{c}-.01 \\
(.01)\end{array}$ & $\begin{array}{c}-.01 \\
(.01)\end{array}$ & $\begin{array}{c}-.02 \\
(.01)\end{array}$ & $\begin{array}{c}.01 \\
(.02)\end{array}$ \\
\hline Unemployment benefit duration & $\begin{array}{c}.04 \\
(.04)\end{array}$ & $\begin{array}{c}.06 \\
(.05)\end{array}$ & $\begin{array}{c}.06 \\
(.05)\end{array}$ & $\begin{array}{l}.10^{*} \\
(.06)\end{array}$ \\
\hline Lagged unemployment $(t-1)$ & $\begin{array}{l}.96^{* *} \\
(.03)\end{array}$ & $\begin{array}{l}.91^{* *} \\
(.03)\end{array}$ & $\begin{array}{l}.94^{* *} \\
(.04)\end{array}$ & $\begin{array}{l}.88^{* *} \\
(.05)\end{array}$ \\
\hline $\mathbf{R}^{2}$ & .95 & .93 & .96 & .95 \\
\hline Durbin's $h$ & 1.51 & 1.49 & 1.33 & 1.25 \\
\hline Number of observations & 288 & 288 & 192 & 96 \\
\hline Wage coordination & & & $\begin{array}{c}-.19^{\mathrm{a}} \\
-.25 \text { to }-.10^{\mathrm{b}} \\
-.20 \text { to }-.13^{\mathrm{c}}\end{array}$ & $\begin{array}{c}.09^{\mathrm{a}} \\
-.11 \text { to } .13^{\mathrm{b}} \\
-.11 \text { to } .09^{\mathrm{c}}\end{array}$ \\
\hline $\begin{array}{l}\text { Union participation in economic policymaking } \\
\times \text { leftist government }\end{array}$ & & & $\begin{array}{c}-.11^{\mathrm{a}} \\
-.16 \text { to }-.05^{\mathrm{b}} \\
-.14 \text { to }-.08^{\mathrm{c}}\end{array}$ & $\begin{array}{c}-.29^{\mathrm{a}} \\
-.54 \text { to }-.24^{\mathrm{b}} \\
-.53 \text { to }-.20^{\mathrm{c}}\end{array}$ \\
\hline
\end{tabular}

Note: Numbers in parentheses are panel-corrected standard errors. Results for year dummies (Models 1, 3, and 4) are not shown.

${ }^{a}$ Coefficient in a regression with the other corporatism variable omitted.

b Range of coefficients in regressions with countries omitted one at a time ("jackknife").

c Range of coefficients in regressions with all possible combinations of the control variables ("extreme bounds").

${ }^{*} p<.05 \quad{ }^{* *} p<.01$ (one-tailed tests) 
exactly equals the oppositely signed coefficient for the interaction term (which estimates the change in effect between 1980 1991 and 1992-1997). ${ }^{9}$ Why 1992 ? One possible reason is that, although 1990 is commonly identified as the beginning of the 1990s business cycle (see OECD various years), that is largely based on the fact that the U.S. economy went into recession in that year. Most of Europe, by contrast, did not enter the downturn until around 1992. Of course, any such break in effects is unlikely to have occurred simultaneously across all countries or even to have taken place sharply and decisively in a single year within any given individual country. Models 3 and 4 show separate regressions for 1980-1991 and 1992-1997. They reinforce the results in Model 2: Wage coordination was associated with superior unemployment performance in the 1980 s, but in the 1990 s that association disappeared.

Note that these regressions assess change in unemployment outcomes, as they include the lagged unemployment rate as a regressor. If the lagged dependent variable is dropped, the wage-coordination variable is negatively signed and easily statistically significant in the 1992-1997 regression (not shown). In other words, controlling for other relevant determinants, countries with greater wage coordination continued to enjoy lower unemployment rates in the 1990s. However, the Table 2 results, with the lagged unemployment rate included, suggest that this was a legacy of superior performance in earlier decades.

Table 2 includes results of two sets of robustness tests for the 1980-1991 and 19921997 regressions. The first test drops each country one at a time ("jackknife"). Outliers may be of particular concern for the 1990s: Finland experienced a deep economic shock

${ }^{9} \mathrm{I}$ also explored this issue using period averages for the two decades instead of annual observations. The data were pooled (yielding 32 observations) and a wage coordination $\times 1990$ s period interaction term entered in the regression. As with the regressions using yearly data, the wage-coordination variable is negatively signed and statistically significant, while the wage coordination $x$ 1990 s interaction term is positively signed and also significant. Results for the other variables are generally consistent with those in Table 2 . due to the sudden collapse of the Soviet market, Germany took on the burden of unification, Norway benefited from substantial oil revenues, the United States lowered its unemployment rate in part by incarcerating a larger share of its unskilled males, and so on (Smith 1999; Western and Beckett 1999). The second test reestimates the regressions with all possible combinations of the control variables ("extreme bounds"). Both tests suggest that the results for the wage-coordination variable are reasonably robust.

What accounts for this shift in the relationship between wage coordination and unemployment? Figure 1 indicates that, aside from Finland and Sweden, countries with coordinated wage-setting generally did not perform worse in the 1990s than in the 1980s. Indeed, several high-coordination countries, such as the Netherlands, Belgium, and Denmark, experienced markedly better unemployment performance in the 1990s than in the previous decade. Instead, the difference between the two periods is attributable mainly to the fact that low-coordination countries-Canada, France, the United Kingdom, and the United States-improved their performance. ${ }^{10}$

To understand why the impact of wage coordination disappeared in the 1990s, we need to know the mechanism(s) through which wage coordination affected joblessness in the 1980s. If the effect of wage coordination on unemployment worked through labor cost moderation, economic growth, and/or government policies, entering these variables into the 1980 s regression should reduce the size of the coefficient for the wage-coordination variable. Table 3 shows the results of doing this. They suggest some support for the conventional notion that the

10 It is worth emphasizing the substantial cross-country variation in unemployment performance evident in Figure 1. In the 1980s, there was virtually no increase in joblessness relative to 1974-1979 in Japan, Sweden, Switzerland, Finland, and the United States, whereas in the Netherlands, Belgium, France, Ireland, and the United Kingdom the unemployment rate rose by more than four percentage points. In the 1990s, the spread was even more pronounced, with several countries achieving reductions of two percentage points or better while others experienced increases of four percentage points or more. 

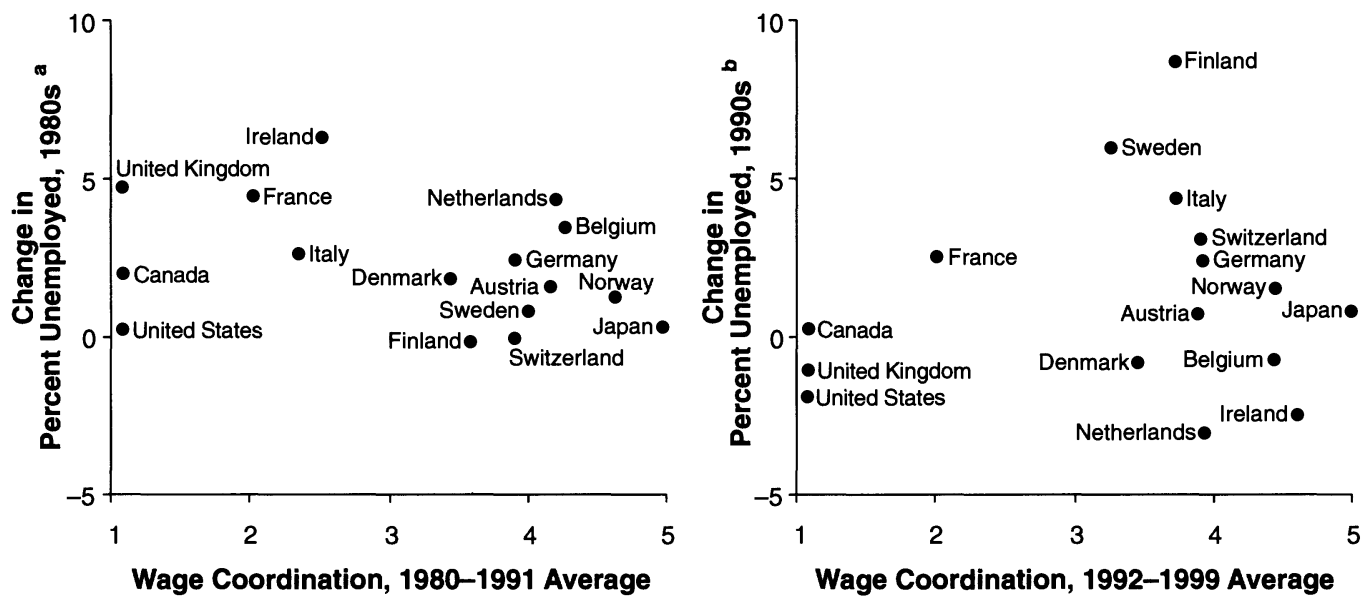

Figure 1. Wage Coordination and Unemployment Performance in the 1980s and 1990s

a 1980-1991 average percent unemployed minus 1974-1979 average.

b 1992-1999 average percent unemployed minus 1980-1991 average.

mechanism linking wage coordination with superior unemployment performance in the 1980 s was labor cost restraint. When the real labor cost index is added, the wage-coordination coefficient decreases (Model 2). Yet the magnitude of the decrease is small. ${ }^{11}$

However, simply entering labor costs as an intervening variable may not accurately capture its role as a causal mechanism. The hypothesized causal sequence links slower growth of real labor costs with lower unemployment, but low unemployment enhances workers' bargaining power and thereby likely leads to faster increases in wages and labor

11 This could stem from the time frame used here. If wage coordination affects unemployment via its impact on real labor costs, that effect may not be observable in the very short run. Regressions that examine a longer period, such as a decade, might be better able to detect it. In analyses not shown here, I estimated an OLS regression using decade-average data for the 1980 s with change in unemployment (1980-1991 average minus 1974-1979 average) as the dependent variable. With only 16 countries, a regression using decade averages for a single period is hindered by limited degrees of freedom. I therefore included various combinations of just two control variables in addition to the wage-coordination variable. The wage-coordination variable is negative and statistically significant, as in the Table 2 regression using annual data. Again, however, adding the labor cost index reduces the size of the wage-coordination coefficient by a relatively small amount. costs (Layard et al. 1991; O'Connell 1994; Volgy, Schwarz, and Imwalle 1996; Western and Healy 1999). These two processes-slow growth of labor costs helping to reduce unemployment, along with low unemployment causing faster growth of labor costs-will partially or fully offset each other.

It is therefore useful to separately examine the effect of wage coordination on labor costs and the effect of labor costs on unemployment. This also makes it possible to explore whether coordination's lack of association with low unemployment in the 1990 s was due to wage coordination no longer being associated with labor cost moderation or to labor cost moderation no longer being associated with low unemployment (or both). Table 4 shows the results of two regressions. In Model 1, the real labor cost index is regressed on lagged labor costs, wage coordination, a wage coordination $\times$ period dummy interaction, unemployment (average of $t, t-1$, and $t-2$ ), and three additional variables that have proved relevant in prior research on determinants of wage developments: inflation, trade, and union density (O'Connell 1994; Volgy et al. 1996; Western and Healy 1999). The results indicate that wage coordination was associated with labor cost restraint in the 1980 s but not in the 1990s. Here the regressions suggest a break point in either 1991,1992 , or 1993 , with slightly stronger support for 1993. In Model 2, un- 
Table 3. Unstandardized OLS Coefficients from Regressions Testing Various Links between Corporatism and Unemployment

\begin{tabular}{|c|c|c|c|c|c|c|}
\hline \multirow[b]{2}{*}{ Independent Variable } & \multicolumn{4}{|c|}{ 1980-1991 } & \multicolumn{2}{|c|}{ 1992-1997 } \\
\hline & Model 1 & Model 2 & Model 3 & Model 4 & Model 5 & Model 6 \\
\hline Wage coordination & $\begin{array}{c}-.19^{* *} \\
(.07)\end{array}$ & $\begin{array}{c}-.16^{*} \\
(.07)\end{array}$ & $\begin{array}{c}-.17^{*} \\
(.08)\end{array}$ & $\begin{array}{c}-.14^{*} \\
(.08)\end{array}$ & - & - \\
\hline $\begin{array}{l}\text { Union participation in economic } \\
\text { policymaking } \times \text { leftist government }\end{array}$ & - & - & - & - & $\begin{array}{l}-.31^{* *} \\
(.07)\end{array}$ & $\begin{aligned}-.15^{*} \\
(.07)\end{aligned}$ \\
\hline
\end{tabular}

Note: Numbers in parentheses are panel-corrected standard errors.

Model 1: Same variables as in Table 2, Model 3.

Model 2: Same variables as in Table 2, Model 3 plus real labor costs variable.

Model 3: Same variables as in Table 2, Model 3 plus real GDP variable.

Model 4: Same variables as in Table 2, Model 3 plus government expenditures on education variable, government expenditures on active labor market policy variable, and government employment variable.

Model 5: Same variables as in Table 2, Model 4.

Model 6: Same variables as in Table 2, Model 4 plus total government expenditures variable, government expenditures on education variable, government expenditures on active labor market policy variable, and government employment variable.

${ }^{*} p<.05 \quad{ }^{* *} p<.01$ (one-tailed tests)

employment is regressed on the same set of variables as in Table 2, except that wage coordination is replaced by the labor cost index. Faster growth of labor costs is associated with higher unemployment throughout both decades; there is no evidence of a break in effects. (Hence no period dummy interaction term is included in Model 2.) Thus, consistent with the assumption underlying much of the prior research on corporatist wage-setting, the evidence suggests that in the 1980 s wage coordination helped to reduce unemployment by fostering real labor cost restraint. However, although labor cost moderation continued to contribute to low unemployment in the 1990 s, countries with coordinated wage-setting were no longer better at securing such moderation.

Can we safely presume, based on these findings, that the causal path in the 1980s truly was wage coordination $\rightarrow$ real labor cost moderation $\rightarrow$ low unemployment? Perhaps some countries with rapid growth in labor costs and/or high unemployment in the late 1970 s or 1980 s shifted to fragmented wage bargaining in the hope that reducing institutional "rigidities" would solve their labor market problems. If such nations were unable to turn things around, their poor performance in the 1980s would suggest that low coordination yields poor labor market outcomes when in fact it would be more ac- curate to reverse the direction of the causal arrows.

Figure 2 provides some case study insight into this issue. It shows year-by-year developments in wage coordination, real labor costs, and unemployment in six relevant countries in the 1970s, 1980s, and 1990s. Canada, France, the United Kingdom, and the United States have consistently had the least coordinated wage-setting arrangements among the 16 nations, and Denmark and Sweden shifted from high to intermediate coordination during the 1980s. The charts suggest that Canada, France, and the United States almost certainly are not countries for which reverse causality is plausible. None of these three experienced any noteworthy change in wage coordination over time, aside from brief periods of wage-price controls in Canada and the United States during the early 1970s. Nor was there reverse causality in Sweden, as its unemployment rate remained quite low throughout the 1980 s even as wage bargaining became less coordinated.

The United Kingdom and Denmark are more likely candidates. Both suffered a sharp rise in unemployment in the early 1980 s, just as they shifted toward less coordinated wage-setting. But did wage militancy generated by wage coordination in earlier years cause these increases in jobless- 
Table 4. Unstandardized OLS Coefficients from Additional Regressions Testing Wage Restraint as a Link between Corporatism and Unemployment

\begin{tabular}{|c|c|c|}
\hline \multirow{3}{*}{$\begin{array}{l}\text { Independent } \\
\text { Variable }\end{array}$} & \multicolumn{2}{|c|}{ Dependent Variable } \\
\hline & $\begin{array}{c}\text { Real } \\
\text { Labor Costs, } \\
1980-1997 \\
\end{array}$ & $\begin{array}{l}\text { Unemploy- } \\
\text { ment, } \\
1980-1997 \\
\end{array}$ \\
\hline & Model 1 & Model 2 \\
\hline Wage coordination & $\begin{array}{l}-.26^{* *} \\
(.09)\end{array}$ & - \\
\hline $\begin{array}{l}\text { Wage coordination } \\
\times 1993-1997 \text { period } \\
\text { dummy }\end{array}$ & $\begin{array}{l}.21^{*} \\
(.11)\end{array}$ & - \\
\hline $\begin{array}{l}\text { 1993-1997 period } \\
\text { dummy }\end{array}$ & $\begin{array}{c}-1.43^{* *} \\
(.48)\end{array}$ & - \\
\hline Unemployment & $\begin{array}{l}-.14^{* *} \\
(.04)\end{array}$ & - \\
\hline Inflation & $\begin{array}{l}-.11^{* *} \\
(.04)\end{array}$ & - \\
\hline Real labor cost index & - & $\begin{array}{l}3.58^{* *} \\
(1.29)\end{array}$ \\
\hline $\begin{array}{l}\text { Union participation in } \\
\text { economic policymaking } \times \\
\text { leftist government }\end{array}$ & $\times$ & $\begin{array}{l}-.10 \\
(.06)\end{array}$ \\
\hline $\begin{array}{l}\text { Union participation in } \\
\text { economic policymaking }\end{array}$ & - & $\begin{array}{l}-.00 \\
(.04)\end{array}$ \\
\hline Leftist government & - & $\begin{array}{l}.95^{* *} \\
(.37)\end{array}$ \\
\hline Trade & $\begin{array}{l}-.49 \\
(.38)\end{array}$ & $\begin{array}{l}-.03 \\
(.29)\end{array}$ \\
\hline Union density & $\begin{array}{l}.89 \\
(.65)\end{array}$ & $\begin{array}{l}.19 \\
(.37)\end{array}$ \\
\hline $\begin{array}{l}\text { Employment } \\
\text { regulations }\end{array}$ & - & $\begin{array}{c}.04 \\
(.06)\end{array}$ \\
\hline Tax rate on workers & - & $\begin{array}{l}-.00 \\
(.01)\end{array}$ \\
\hline $\begin{array}{l}\text { Unemployment } \\
\text { benefit duration }\end{array}$ & - & $\begin{array}{l}-.02 \\
(.05)\end{array}$ \\
\hline $\begin{array}{l}\text { Lagged real labor costs } \\
\qquad(t-1)\end{array}$ & $\begin{array}{l}.93^{* *} \\
(.03)\end{array}$ & - \\
\hline $\begin{array}{l}\text { Lagged unemployment } \\
(t-1)\end{array}$ & - & $\begin{array}{l}.98^{* *} \\
(.02)\end{array}$ \\
\hline $\mathrm{R}^{2}$ & .93 & .95 \\
\hline Durbin's $h$ & 1.31 & 1.47 \\
\hline Number of observations & 288 & 288 \\
\hline
\end{tabular}

Note: Numbers in parentheses are panel-corrected standard errors. In Model 1, all coefficients, except that for lagged real labor costs, are multiplied by 100. Results for year dummies (Model 2) are not shown.

$$
{ }^{*} p<.05 \quad{ }^{* *} p<.01 \text { (one-tailed tests) }
$$

ness? Britain certainly suffered from rapid increases in real labor costs in the mid1970s, but arguably despite rather than because of its temporary attempt at a national incomes policy during that period (Flanagan, Soskice, and Ulman 1983; Scharpf [1987] 1991). Moreover, the sharp rise in unemployment beginning in 1980 was largely an explicit aim of the Thatcher government's restrictive monetary policy, a centerpiece of its efforts to curtail the power of organized labor (Rhodes 2000). Denmark, too, experienced above average increases in real labor costs in the mid-1970s, which contributed to growing unemployment in those years. But the very high levels of joblessness in the 1980s were at least as much, if not more, a product of Denmark's hard currency arrangement, which forced the country to adhere to the German Bundesbank's policy of tight money (Benner and Vad 2000). Overall, then, the conclusion that wage coordination was conducive to low unemployment in the 1980 s may be somewhat affected by reverse causality, but the magnitude of that bias probably is not large.

What about reverse causality in the 1990s? The regression results suggest that the association between wage coordination and low unemployment eroded in that decade, but might that be because high or rising levels of joblessness spurred an increase in wage coordination in some countries? Two nations-Ireland and Italy-shifted from low to high coordination in the 1990s (see Figure 1), and in both countries the aim was to restrain wages and thereby reduce unemployment. However, Ireland was quite successful at lowering unemployment in 1990s, while Italy did not fare particularly well. Hence, these two cases probably offset one another, so that the regression results were unaffected. The jackknife analyses indicate that removing either or both does not alter the findings.

Is the finding of no association between wage coordination and unemployment performance in the 1990s a result of a misspecification of the functional form of the relationship? Calmfors and Driffill (1988) and others have posited a hump-shaped relationship between wage-bargaining centralization and labor cost changes, whereby low and high levels of centralization are best at 



Figure 2. Wage Coordination, Real Labor Costs, and Unemployment by Year: Selected Countries, 1973 to 1999

Note: Bars represent wage coordination scores (left axis applies). Dashed lines represent the real labor cost index, with $1973=10$ (right axis applies). Solid lines represent percentage unemployed (right axis applies).

generating labor cost restraint and thus lower unemployment. However, several follow-up studies of the relationship between wage centralization and unemployment find little or no support for this view (OECD 1997; Traxler and Kittel 2000), and the logic is not compelling when applied to wage coordination (Soskice 1990). Another promi- nent view holds that the moderating effect of corporatist wage-setting institutions on labor costs is contingent on the presence of a leftist government (Alvarez et al. 1991; Garrett 1998). Still another view suggests that wage-setting arrangements may interact with central bank independence in determining labor cost developments (Franzese 1999; 
Hall and Franzese 1998; Iversen 1999). In auxiliary regressions not shown here I tested each of these alternative specifications. None is supported.

Do the regression analyses suggest no effect of wage coordination in the 1990s because of multicollinearity? The two corporatism variables correlate at .66 in that decade, compared with .41 in the 1980 s. However, the findings for wage coordination are robust to exclusion of the union participation variable, as is indicated by the figures at the bottom of Model 4 in Table 2.

Unemployment dropped sharply in Sweden and several other countries in the late 1990s. Perhaps the fact that the analyses here extend only to 1997 is responsible for the apparent lack of association between wage coordination and unemployment performance in the 1990s. However, a reestimation of the regression in Model 4 of Table 2 (not shown) adding the years 1998 and 1999 and dropping the union participation variable (due to lack of data) suggests not. The wagecoordination variable in this regression is positive, although not statistically significant.

The second hypothesized causal link between wage coordination and unemployment is economic growth. The regressions indicate some support for this mechanism: When the real GDP index is added to the 1980s regression, the wage-coordination coefficient decreases somewhat, though not a great deal (Model 3 in Table 3).

What about the possibility that wage coordination lowers unemployment via government policy? The hypothesis here is that policymakers presume wage coordination will engender labor cost moderation, and hence that inflationary pressures will be minimal. This encourages governments to pursue more vigorous anti-unemployment programs. Entering the five policy variables one by one into the 1980 s regression suggests that only education expenditures, active labor market policy, and government employment are likely channels linking wage coordination with low unemployment. Model 4 in Table 3 shows the result for the wage coordination coefficient when these three policy variables are added to the Table 2 regression. The wage-coordination coefficient decreases from -.19 to -.14 .
It appears, then, that wage coordination contributed to low unemployment in the 1980s via labor cost moderation, economic growth, and government policies (and perhaps other as-yet-undiscovered mechanisms). Does this explain the lack of effect in the 1990s? The scatterplots in Figure 1 indicate that the key change in the 1990s was that low-coordination countries improved their unemployment performance, not that high-coordination countries began to perform worse. Figure 2 suggests that labor cost moderation was important in Canada and the United States, as real labor costs decreased by nearly 10 percent in these two countries during the 1990s. Labor cost restraint may also have played a role in Britain's decline in joblessness (Nickell and Van Ours 2000), though there was little actual decline in real labor costs in the 1990s. In fact, between 1980 and 1999, labor costs fell just 5 percent in the United Kingdom, compared with 15 percent in both Canada and the United States. Other institutional changes may have been more important in Britain, such as the loosening of restrictions on firing (Deakin and Reed 2000). In France, another country with relatively uncoordinated wage-setting, expansion of public employment seems to have played an important role. Indeed, France was one of only four affluent OECD countries to increase the proportion of its working-age population employed by the government during the 1990s (OECD 2001). In Denmark, which has had an intermediate level of wage coordination, a sizable expansion in active labor market policy in the mid1990s contributed to a dramatic fall in unemployment in the last half of that decade (Auer 2000; Benner and Vad 2000; Björklund 2000).

\section{UNION PARTICIPATION IN ECONOMIC POLICYMAKING}

For union participation in economic policymaking, the second form of corporatism examined here, the story is different. The regression results in Table 2 suggest that, conditional on the presence of a leftist government, union participation tended to be associated with lower unemployment in both the 1980 s and the 1990s. The estimates in Model 2 indicate that this effect grew stronger be- 
ginning in the early 1990s. This is indicated by the statistically significant negative coefficient for the union participation $\times$ leftist government interaction term (which, in Model 2, estimates the effect in the period 1980-1991) and the significant negative coefficient for the three-way union participation $\times$ leftist government $\times 1992-1997$ period dummy interaction term (which estimates the change in effect between 19801991 and 1992-1997). The data suggest roughly equal support for a break in the effect of union participation in 1991, 1992, or 1993. I show the results using 1992 as the break-point simply for symmetry with the wage coordination break. The findings for the separate 1980-1991 and 1992-1997 regressions in Models 3 and 4 are consistent with those in Model 2. (In Model 3, the union participation $\times$ leftist government interaction term is just shy of significance: $p=$ .06.) And the results of the jackknife and extreme bounds tests, shown at the bottom of the table, indicate that these findings are robust to the group of countries included and to model specification. Regressions in which the union participation variable was not interacted with leftist government indicate no support for a direct effect in either decade (not shown here).

Models 5 and 6 in Table 3 show that adding four of the policy variables-total government expenditures, spending on education, spending on active labor market policy, and public employment-reduces the size of the union participation $\times$ leftist government interaction coefficient from -.31 to -.15 . This suggests that participation by unions in the economic policymaking process reduced unemployment mainly, though perhaps not exclusively, via its influence on government policies and programs.

I examined the sensitivity of results for my (expanded) Compston measure by substituting the only other existing time-varying measure of union participation in economic policymaking: that of Traxler et al. (2001: 76). Over the 1980-1997 period, these two measures correlate at .72. The findings (not shown) turn out to be reasonably robust, although with the Traxler-Blaschke-Kittel measure there is no indication of a strengthening of union participation's unemployment-reducing effect in the 1990s.

\section{CONCLUSION}

I have attempted to enhance our understanding of corporatism's macroeconomic effects by answering three questions: (1) Which of the two principal forms of corporatismcorporatist wage-setting or union participation in economic policymaking, or bothhas helped to reduce unemployment? (2) What are the causal mechanisms? (3) Did these effects continue in the 1990s in the face of globalization, restrictive monetary policy, growing dissension within labor movements, and related developments?

It is important to be cautious in interpreting my findings. The two corporatism variables are based on subjective judgment and thus are susceptible to measurement error. In addition, these analyses are highly aggregated; they may or may not shed light on the experiences of any particular nation. Broad statistical analyses such as this need to be supplemented by in-depth country case studies.

With these caveats noted, the findings here suggest that coordinated wage-setting was associated with low unemployment in the 1980s. There are compelling theoretical reasons to suspect that this effect worked through real labor cost restraint, economic growth, and government anti-unemployment policies, and each of these mechanisms receives empirical support in the analyses. In the 1990s the association between wage coordination and superior unemployment performance disappeared, mainly because lowcoordination countries performed better in the 1990s than they did in the 1980s. By the early 1990s, the balance of power between workers and employers in at least some lowcoordination countries appears to have shifted to a point where unions were considerably less able to disrupt market processes. Students of corporatism have long recognized the potential for substantial moderation of labor costs in countries with weak labor (Alvarez et al. 1991; Calmfors and Driffill 1988). Fragmented bargaining structures create an incentive for union militancy, but this incentive is immaterial if unions are sufficiently weak. In the 1970 s and 1980 s, unions in low-coordination countries evidently were strong enough that the incentive did matter, but that was no longer the case 
in the 1990s. Hence, wage coordination was no longer a prerequisite for labor cost restraint.

Has corporatism, then, become irrelevant for labor market outcomes? I answer no, for two reasons. First, beneficial effects of corporatist institutions on unemployment performance were still observable in the 1990s, but they were generated by union participation in economic policymaking rather than by wage coordination. The causal link appears to be anti-unemployment policies such as general government spending, education, active labor market policy, and public employment. Although union participation in policymaking was a central concern in the early-1980s corporatist literature (Lehmbruch 1984), it has received scant attention in empirical research on corporatism's macroeconomic effects. The findings here seem to warrant renewed interest.

Second, other researchers find an association between corporatism and low levels of earnings inequality, and the structure of wage-setting arrangements is responsible for this association (Alderson and Nielsen forthcoming; Lucifora 2000; Rueda and Pontusson 2000; Wallerstein 1999). Coordinated and/or centralized wage arrangements may no longer be advantageous for securing low unemployment, but as long as they are no worse in this respect than fragmented wage structures and better at limiting pay inequality, they are likely to remain prominent in the institutional landscapes of affluent capitalist nations.

Lane Kenworthy is Assistant Professor of Sociology at Emory University. His research focuses on the effects of institutions and government policies on socioeconomic performance in affluent countries. His publications include In Search of National Economic Success: Balancing Competition and Cooperation (Sage, 1995) and recent articles in the American Journal of Sociology, Social Forces, and World Politics.

\section{REFERENCES}

Ahlen, Kristina. 1989. "Swedish Collective Bargaining under Pressure: Inter-Union Rivalry and Incomes Policies." British Journal of Industrial Relations 27:330-46.

Alderson, Arthur S. and François Nielsen. Forthcoming. "Globalization and the Great U-Turn: Income Inequality Trends in 16 OECD Coun- tries." American Journal of Sociology.

Alvarez, R. Michael, Geoffrey Garrett, and Peter Lange. 1991. “Government Partisanship, Labor Organization, and Macroeconomic Performance." American Political Science Review 85:539-56.

Auer, Peter. 2000. Employment Revival in Europe: Labor Market Success in Austria, Denmark, Ireland, and the Netherlands. Geneva, Switzerland: International Labour Organization.

Beck, Nathaniel and Jonathan N. Katz. 1995. "What To Do (and Not To Do) with Time-Series Cross-Section Data." American Political Science Review 89:634-47.

. 2001. "Throwing Out the Baby with the Bath Water: A Comment on Green, Kim, and Yoon." International Organization 55:487-95.

Benner, Mats and Torben Bundgaard Vad. 2000. "Sweden and Denmark: Defending the Welfare State." Pp. 399-466 in Welfare and Work in the Open Economy, vol. 2, Diverse Responses to Common Challenges, edited by F. W. Scharpf and V. A. Schmidt. New York: Oxford University Press.

Berger, Suzanne and Ronald Dore, eds. 1996. National Diversity and Global Capitalism. Ithaca, NY: Cornell University Press.

Björklund, Anders. 2000. "Going Different Ways: Labour Market Policy in Denmark and Sweden." Pp. 148-80 in Why Deregulate Labour Markets?, edited by G. EspingAndersen and M. Regini. New York: Oxford University Press.

Boix, Carles. 1998. Political Parties, Growth, and Equality. New York: Cambridge University Press.

. 2000. "Partisan Governments, the International Economy, and Macroeconomic Policies in Advanced Nations, 1960-93." World Politics 53:38-73.

Boreham, Paul and Hugh Compston. 1992. "Labour Movement Organization and Political Intervention: The Politics of Unemployment in the OECD Countries, 1974-1986." European Journal of Political Research 22:143-70.

Bruno, Michael and Jeffrey D. Sachs. 1985. Economics of Worldwide Stagflation. Cambridge, MA: Harvard University Press.

Calmfors, Lars and John Driffill. 1988. "Bargaining Structure, Corporatism, and Macroeconomic Performance." Economic Policy 6:1461.

Cameron, David R. 1984. "Social Democracy, Corporatism, Labour Quiescence, and the Representation of Economic Interest in Advanced Capitalist Society." Pp. 143-78 in Order and Conflict in Contemporary Capitalism, edited by J. H. Goldthorpe. Oxford, England: Clarendon. 
Campbell, John L. 2000. "States, Politics, and Globalization: Why Institutions Still Matter." Department of Sociology, Dartmouth College, Hanover, NH. Unpublished manuscript.

Centre for Economic Performance (CEP), London School of Economics and Political Science. N.d. "Centre for Economic Performance OECD Dataset." London, England: CEP.

Chiricos, Theodore G. 1987. "Rates of Crime and Unemployment: An Analysis of Aggregate Research Evidence." Social Problems 34:187212.

Clark, Andrew and Andrew Oswald. 1994. "Unhappiness and Unemployment." Economic Journal 104:1025-43.

Compston, Hugh. 1997. "Union Power, Policy Making, and Unemployment in Western Europe, 1972-1993." Comparative Political Studies 30:732-51.

1998. "The End of National Policy Concertation? Western Europe since the Single European Act." Journal of European Public Policy 5:507-26.

Deakin, Simon and Hannah Reed. 2000. "River Crossing or Cold Bath? Deregulation and Employment in Britain in the 1980s and 1990s." Pp. 115-47 in Why Deregulate Labour Markets?, edited by G. Esping-Andersen and $M$. Regini. New York: Oxford University Press.

Dore, Ronald. 1987. Taking Japan Seriously. Stanford, CA: Stanford University Press.

Ebbinghaus, Bernhard and Jelle Visser. 2000. Trade Unions in Western Europe since 1945. London, England: Macmillan.

Esping-Andersen, Gøsta. 1999. Social Foundations of Postindustrial Economies. New York: Oxford University Press.

Flanagan, Robert J. 1999. "Macroeconomic Performance and Collective Bargaining: An International Perspective." Journal of Economic Literature 37:1150-75.

Flanagan, Robert J., David Soskice, and Lloyd Ulman. 1983. Unionism, Economic Stabilization, and Incomes Policies. Washington, DC: Brookings Institution.

Franzese, Robert J., Jr. 1999. "The Interaction of Credibly Conservative Monetary Policy with Labor- and Goods-Market Institutions: A Review of an Emerging Literature." Department of Political Science, University of Michigan, Ann Arbor, MI. Unpublished manuscript.

Garrett, Geoffrey. 1998. Partisan Politics in the Global Economy. New York: Cambridge University Press.

Golden, Miriam, Peter Lange, and Michael Wallerstein. 1997. "Union Centralization among Advanced Industrial Societies: An Empirical Study." Data set. Retrieved May 5, 2001 (http://www.shelley.polisci.ucla.edu/ data).
Hall, Peter A. and Robert J. Franzese, Jr. 1998. "Mixed Signals: Central Bank Independence, Coordinated Wage Bargaining, and European Monetary Union." International Organization 52:505-35.

Hernes, Gudmund. 1991. "The Dilemmas of Social Democracies: The Case of Norway and Sweden." Acta Sociologica 34:239-60.

Hibbs, Douglas A., Jr. 1977. "Political Parties and Macroeconomic Policy." American Political Science Review 71:1467-87.

Hicks, Alexander. 1988. "Social Democratic Corporatism and Economic Growth." Journal of Politics 50:677-704.

Hicks, Alexander and Lane Kenworthy. 1998. "Cooperation and Political Economic Performance in Affluent Democratic Capitalism." American Journal of Sociology 103:1631-72.

Im, Kyung So, M. Hashem Pesaran, and Yongcheol Shin. 1997. "Testing for Unit Roots in Heterogeneous Panels." Department of Applied Economics, University of Cambridge, Cambridge, England. Unpublished manuscript (available at: http://www.econ.cam.ac.uk/faculty/pesaran/lm.pdf).

Iversen, Torben. 1999. Contested Economic Institutions. New York: Cambridge University Press.

Janoski, Thomas, Christa McGill, and Vanessa Tinsley. 1997. "Making Institutions Dynamic in Cross-National Research: Time-Space Distancing in Explaining Unemployment." Comparative Social Research 16:227-68.

Kenworthy, Lane. 1996. "Unions, Wages, and the Common Interest." Comparative Political Studies 28:491-524.

- 1997. "Globalization and Economic Convergence." Competition and Change 2:164.

2001a. "Wage-Setting Coordination Scores." Version dated June 17, 2001. Data set. Retrieved June 17, 2001 (http://www. emory.edu/SOC/lkenworthy).

—. 2001b. "Wage-Setting Measures: A Survey and Assessment." World Politics 54:5798.

- 2002. "Do Affluent Countries Face an Incomes-Jobs Tradeoff?" Discussion Paper No. 01/10, Max Planck Institute for the Study of Societies, Cologne, Germany (available at: http://www.mpi-fg-koeln.mpg.de).

Kitschelt, Herbert, Peter Lange, Gary Marks, and John D. Stephens, eds. 1999. Continuity and Change in Contemporary Capitalism. New York: Cambridge University Press.

Korpi, Walter. 1991. "Political and Economic Explanations for Unemployment: A Cross-National and Long-Term Analysis." British Journal of Political Science 21:315-48.

Krugman, Paul. 1998. "The Confidence Game." 
The New Republic, October 5, pp. 23-25.

Layard, Richard, Stephen Nickell, and Richard Jackman. 1991. Unemployment: Macroeconomic Performance and the Labor Market. New York: Oxford University Press.

Lehmbruch, Gerhard. 1984. "Concertation and the Structure of Corporatist Networks." P'p. 60-80 in Order and Conflict in Contemporary Capitalism, edited by J. H. Goldthorpe. Oxford, England: Oxford University Press.

Long, J. Scott and Laurie H. Ervin. 2000. "Using Heteroscedasticity Consistent Standard Errors in the Linear Regression Model." American Statistician 54:217-24.

Lucifora, Claudio. 2000. "Wage Inequalites and Low Pay: The Role of Labour Market Institutions." Pp. 9-34 in Labour Market Inequalities, edited by M. Gregory, W. Salverda, and S. Bazen. New York: Oxford University Press.

Martin, John P. 2000-2001. "What Works among Active Labour Market Policies: Evidence from OECD Countries' Experiences." OECD Economic Studies 30:79-113.

Nickell, Stephen. 1997. "Unemployment and Labor Market Rigidities: Europe versus North America." Journal of Economic Perspectives 11(3):55-74.

Nickell, Stephen and Brian Bell. 1996. "Changes in the Distribution of Wages and Unemployment in OECD Countries." American Economic Review (AEA Papers and Proceedings) 86:302-08.

Nickell, Stephen and Richard Layard. 1999. "Labor Market Institutions and Economic Performance." Pp. 3029-84 in Handbook of Labor Economics, vol. 3C, edited by O. Ashenfelter and D. Card. Amsterdam, Netherlands: Elsevier.

Nickell, Stephen and Jan Van Ours. 2000. "Mirage or Miracle? Labour Market Performance in Britain and the Netherlands." CentrePiece, spring. Retrieved June 6, 2000 (http://www. centrepiece-magazine.com).

O'Connell, Philip J. 1994. "National Variation in the Fortunes of Labor: A Pooled and CrossSectional Analysis of the Impact of Economic Crisis in the Advanced Capitalist Nations." Pp. 218-42 in The Comparative Political Economy of the Welfare State, edited by T. Janoski and A. Hicks. New York: Cambridge University Press.

Okun, Arthur M. 1973. "Upward Mobility in a High-Pressure Economy." Brookings Papers on Economic Activity 1:207-52.

Organization for Economic Cooperation and Development (OECD). 1997. "Economic Performance and the Structure of Collective Bargaining." Pp. 63-93 in OECD Employment Outlook. Paris, France: OECD.

2001. OECD Statistical Compendium
01\#2001 [MRDF]. Paris, France: OECD [producer and distributor].

- Various years. OECD Historical Statistics. Paris, France: OECD.

N.d. "OECD Education Database." Data set. Retrieved May 5, 2001 (http://www.oecd. org/els/stats/edu_db/edu_db.htm).

Pochet, Philippe and Guiseppe Fajertag, eds. 1997. Social Pacts in Europe. Brussels, Belgium: European Trade Union Institute.

Rhodes, Martin. 2000. "Restructuring the British Welfare State: Between Domestic Constraints and Global Imperatives." Pp. 13-68 in Welfare and Work in the Open Economy, vol. 2, Diverse Responses to Common Challenges, edited by F. W. Scharpf and V. A. Schmidt. New York: Oxford University Press.

Rueda, David and Jonas Pontusson. 2000. "Wage Inequality and Varieties of Capitalism." World Politics 52:350-83.

Scarpetta, Stefano. 1996. "Assessing the Role of Labour Market Policies and Institutional Settings on Unemployment: A Cross-Country Study." OECD Economic Studies 26:43-98.

Scharpf, Fritz W. [1987] 1991. Crisis and Choice in European Social Democracy. Translated by R. Crowley and F. Thompson. Ithaca, NY: Cornell University Press.

1999. Governing in Europe: Effective and Democratic? New York: Oxford University Press.

Scharpf, Fritz W. and Vivien A. Schmidt, eds. 2000. Welfare and Work in the Open Economy, vol. 1, From Vulnerability to Competitiveness. New York: Oxford University Press.

Smith, Michael R. 1999. "Doing Well by Doing Good? What Happened to Corporatist Countries in the 1990s, and Why?" Presented at the annual meeting of the Society for the Advancement of Socio-Economics, June, Madison, WI.

Soskice, David. 1990. "Wage Determination: The Changing Role of Institutions in Advanced Industrialized Countries." Oxford Review of Economic Policy 6(4):36-61.

1999. "Divergent Production Regimes: Coordinated and Uncoordinated Market Economies in the 1980s and 1990s." Pp. 10134 in Continuity and Change in Contemporary Capitalism, edited by $\mathrm{H}$. Kitschelt, P. Lange, G. Marks, and J. D. Stephens. New York: Cambridge University Press.

2000. "Macroeconomic Analysis and the Political Economy of Unemployment.” Pp. 3874 in Unions, Employers, and Central Banks, edited by T. Iversen, J. Pontusson, and D. Soskice. New York: Cambridge University Press.

Streeck, Wolfgang. 1984. "Neo-Corporatist Industrial Relations and the Economic Crisis in West Germany." Pp. 291-314 in Order and 
Conflict in Contemporary Capitalism, edited by J. H. Goldthorpe. Oxford, England: Clarendon.

1997. “German Capitalism: Does It Exist? Can it Survive?" New Political Economy 2:237-56.

Swank, Duane. N.d. “18-Nation Pooled Time-Series Data Set: Strength of Political Parties by Ideological Group in Advanced Capitalist Countries." Data set. Retrieved October 10, 2001 (http://www.marquette.edu/polisci/ Swank.htm).

Therborn, Göran. 1986. Why Some Peoples Are More Unemployed than Others. London, England: Verso.

Traxler, Franz, Sabine Blaschke, and Bernhard Kittel. 2001. National Labour Relations in Internationalized Markets. New York: Oxford University Press.

Traxler, Franz and Bernhard Kittel. 2000. "The Bargaining System and Performance: A Comparison of 18 OECD Countries." Comparative Political Studies 33:1154-90.

U.S. Bureau of Labor Statistics. N.d. "Comparative Civilian Labor Force Statistics, Ten Countries, 1959-2000." Data set. Retrieved May 5, 2001 (http://stats.bls.gov/fls/home.htm).

Visser, Jelle and Anton Hemerijck. 1997. "A Dutch Miracle": Job Growth, Welfare Reform, and Corporatism in the Netherlands. Amsterdam, Netherlands: Amsterdam University Press.

Volgy, Thomas J., John E. Schwarz, and
Lawrence E. Imwalle. 1996. "In Search of Economic Well-Being: Worker Power and the Effects of Productivity, Inflation, Unemployment, and Global Trade on Wages in Ten Wealthy Countries." American Journal of Political Science 40:1233-52.

Wallerstein, Michael. 1999. "Wage-Setting Institutions and Pay Inequality in Advanced Industrial Societies." American Journal of Political Science 43:649-80.

Western, Bruce. 2001. "Institutions, Investment, and the Rise in Unemployment." Pp. 71-93 in The Rise of Neoliberalism and Institutional Analysis, edited by J. L. Campbell and O. K. Pedersen. Princeton, NJ: Princeton University Press.

Western, Bruce and Katherine Beckett. 1999. "How Unregulated Is the U.S. Labor Market? The Penal System as a Labor Market Institution." American Journal of Sociology 104: 1030-60.

Western, Bruce and Kieren Healy. 1999. "Explaining the OECD Wage Slowdown: Recession or Labour Decline?" European Sociological Review 15:233-49.

Wilson, William Julius. 1996. When Work Disappears. New York: Vintage.

Windolf, Paul. 1989. "Productivity Coalitions and the Future of European Corporatism." Industrial Relations 28:1-20.

Woodall, Pam. 1995. "A Survey of the World Economy." The Economist, October 7, pp. 138. 